\title{
A Chlorotic Streak Disease of Merker Grass (Pennisetum purpureum)
}

\author{
G.W. Bruehl and Efrain Boneta García
}

\section{INTRODUCTION}

In the summer of 1952, near Coloso, P.R., chlorotic streaks, sometimes discontinuous, and with wavy margins, were observed running for various lengths on large, expanded leaves of Pennisetum purpureum Schumac. Microscopic examinations gave no evidence of an associated pathogen. The similarity of these streaks to those of chlorotic streak disease of sugarcane, and the occurrence of heavily diseased sugarcane in an adjoining field, suggested that they might have the same causal agent.

Cuttings of selected diseased stems of $P$. purpureum were subjected to the hot-water treatment effective in rendering sugarcane free from the chlorotic streak virus of that host (7), ${ }^{2}$ and the grass was rendered diseasefree. The hypothesis that these diseases might be the same was supported by the fact that the chlorotic streak-diseased grass was found growing in association with chlorotic streak-diseased sugarcane, it occurred most abundantly in humid areas known to favor this disease in sugarcane, the same hot-water treatment was effective in control, and the leaf-blade symptoms were similar $(4,5)$. As no hosts of chlorotic streak of sugarcane other than Saccharum spp. were known, other grasses were examined for the possible presence of this disease.

Similar symptoms were found in several strains of Pennisetum purpureum, in hybrids of $P$. glaucum and $P$. purpureum, in Panicum maximum L., and in Erianthus spp. (5). The Erianthus grasses are closely related to sugarcane and are fertile in crosses with cane, but the other two genera are further removed, particularly $P$. maximum. Erianthus arundinaceus was grown in a sugarcane-breeding nursery and symptoms were more evident on it than on the sugarcanes. The chlorotic streaks were observed on P. maximum only at Río Piedras in a low, wet clay-soil area, and as this grass is generally grown in the more arid regions it may not suffer economic losses.

Strains of $P$. purpureum, particularly Merker grass, are widely cultivated

${ }^{1}$ Formerly Pathologist and Agronomist, respectively, Agricultural Research Service, U.S. Department of Agriculture, in cooperation with the Agricultural Experiment Station, University of Puerto Rico, Río Piedras, P.R. The authors wish to express their appreciation for the guidance throughout this work of E. V. Abbott, Sugar Plant Investigations, U.S. Department of Agriculture, Houma, La.

${ }^{2}$ Numbers in parentheses refer to Literature Cited, p. 196-7. 
in the humid parts of the Island, and are a mainstay in the livestock enterprises. Knowledge as to the host range of the virus would aid in sugarcane-breeding work. It would be important to know whether these and other grasses are hosts of the sugarcane chlorotic streak virus and aid in increasing the populations of insect vectors, and in these roles constitute a hazard to the sugarcane crop and industry. In Louisiana the chlorotic streak-disease virus is transmitted by the leaf hopper, Draeculacephala portola (3), but no transmission studies were conducted to determine definitely the relationships among these apparently similar diseases in Puerto Rico.

Merker grass, a commercial strain of $P$. purpureum widely grown in humid areas, is of major importance in its own right, regardless of any possible role as an additional host of a major disease of sugarcane. It is regetatively propagated and withstands the hot-water treatment well.

\section{METHODS AND RESUITS}

The observations reported herein indicate the value of using diseasefree Merker grass seed, that there are differences in susceptibility among strains of $P$. purpureum, and that the chlorotic streak disease of that grass is capable of causing heavy losses in forage production.

\section{EXPERIMENT 1}

Several strains and hybrids of Pennisetum spp. were grown along with other grasses in a comparative-yield experiment in the low wet lands of the Experiment Station at Río Piedras. This trial was adjacent to sugarcane suffering from chlorotic-streak disease. The seed ${ }^{3}$ of this trial came from two sources: Increase blocks adjacent to diseased cane, and a grass nursery somewhat isolated from sugarcane. These grasses were observed for the presence of chlorotic streak symptoms to detect any differences in degree of infection present among grass strains, and the influence of seed source on the extent of the disease present (table 1).

The incidence of the disease present was influenced by both seed source and strain of the grass. Those grasses grown from seed sources adjacent to diseased cane were infected to a greater degree than those from the grass nursery. The fourth grass listed in table 1 had become far more diseased than any other present in the trial. This disease should be considered in the development of strains of $P$. purpureum for the humid areas, but of more importance would be a program to eliminate the disease through the use of clean seed.

${ }^{3}$ In the case of $P$. purpureum "seed" refers to vegetative stem cuttings, usually" of three nodes, the same as in sugarcane. 
TABLE 1.-Chlorotic streak disease observed in a grass trial at Río Piedras

\begin{tabular}{l|c|c}
\hline \multicolumn{1}{c|}{ Grass } & $\begin{array}{c}\text { Number of plants } \\
\text { diseased, Aug. 2, } \\
\text { 1953 }\end{array}$ & $\begin{array}{c}\text { Disease rating } \\
\text { July 30, 1954 }\end{array}$ \\
\hline 1. Merker, Pennisetum purpureum & - & $34^{2}$ \\
2. Elephant, P. purpureum & - & 19 \\
3. Merkeron, P. purpureum & 10 & $31^{2}$ \\
4. 29722 X short (16 X 18 (3:1)), P. purpureum & 218 & $544^{2}$ \\
5. 29722 X short (16 X 18), P. purpureum & 11 & $15^{2}$ \\
6. 29722 X millet 16 (1:1), P. purpurezm $\times P$. & & $61^{2}$ \\
glaucum & 40 & 2 \\
7. Selection 169, P. purpureum & - & 0 \\
8. Guinea (local), Panicum maximum & - & 4 \\
9. Guinea (from Brazil), P. maximum & - & 0 \\
10. Hybrid 73-50, P. purpureum & - & 0 \\
11. Hybrid 73-51, P. purpureum & - & 0 \\
12. Hybrid 73-52, P. purpureum & - & 3 \\
13. Hybrid 73-53, P. purpureum & - & 0 \\
14. Hybrid 73-54, P. purpureum & - & 3 \\
\hline
\end{tabular}

${ }^{1}$ Plants showing leaf symptoms but little or no stunting were rated 1 , moderate stunting 2 , severe stunting 3 , and dead plants 4 .

${ }^{2}$. Seed from the increase block. Seed for the others came from a nursery in which chlorotic streak was rare.

\section{EXPERIMENT 2}

An experiment designed to determine the practicability of the hot-water treatment to prevent chlorotic streak disease on a commercial improved strain of $P$. purpureum (Merker grass) and to provide an estimate of the effect of the disease on yield and quality of forage was conducted at Lajas, P.R., on a black, alkaline, somewhat salty soil where irrigation water was available. The diseased seed was obtained from individually selected stalks with one or more leaves showing clear symptoms of chlorotic streak near Central Coloso ${ }^{4}$ in western Puerto Rico.

Apparently healthy seed was selected at Río Piedras from a field known to be relatively free from this disease. The leaves were removed and the stems cut into 3-node segments. The diseased and apparently healthy seed lots were divided equally. One-half of each lot was treated in hot water $\left(52^{\circ} \mathrm{C}\right.$.) for 20 minutes. It was planted October 8,1953 , in six replicates in plots of four 16-foot rows, 2 feet apart. Each plot of apparently healthy and apparently healthy-treated seed received 30 seed pieces ( 14.5 pounds), and each diseased and diseased-treated plot 45 seed pieces (11 pounds). A greater number of diseased than of disease-free seed pieces was used in an

${ }^{4}$ The authors wish to express their appreciation for the cooperation of the management of Central Coloso, and particularly to Nicolás Cardona and Hector Martínez. 


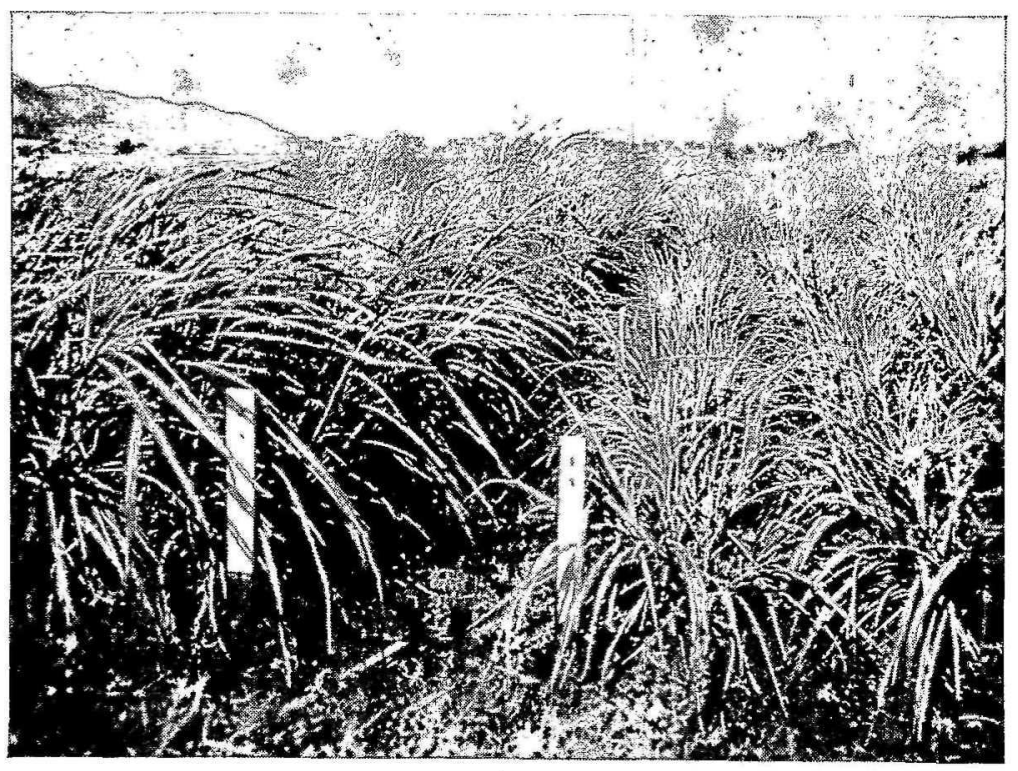

A

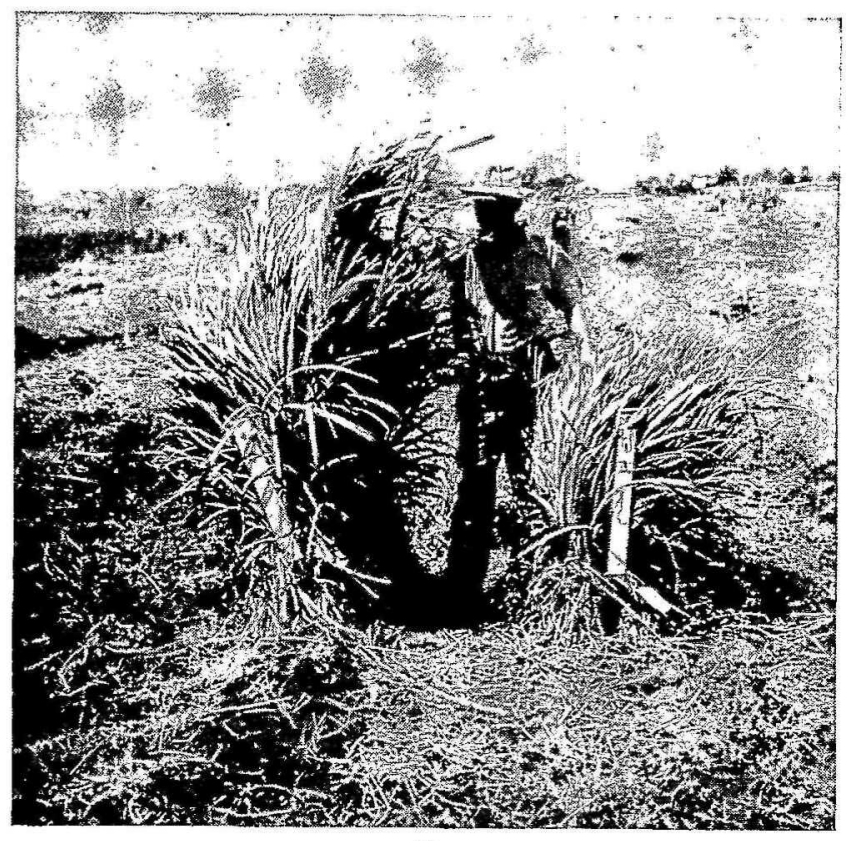

B

FIG. 1.-A, Merker grass in a diseased-treated plot (left) adjacent to a diseased plot (right) is taller, darker green, and the leaves are more turgid. B, The left-hand bundle is from an apparently healthy-treated plot, the right-hand bundle from a diseased plot. 
TABLE 2,- Production of foraye by Merker grass (Pennisetum purpureum var.

Merkerii) from diseased, diseased hot-water-treated, apparently healthy, and

* apparently healthy hot-water-treated lots of seed at Lajas, October 8, 1954January 14, $1955^{1}$

\begin{tabular}{|c|c|c|c|c|c|c|}
\hline \multirow{2}{*}{ Seed lot ${ }^{2}$} & \multicolumn{5}{|c|}{ Yield in pounds for each of 5 cuttings } & \multirow{2}{*}{ Total } \\
\hline & 1 & 2 & 3 & 4 & 5 & \\
\hline Diseased & 103.09 & 91.11 & 161.72 & 296.93 & 84.76 & $146.6 \pm$ \\
\hline Diseased-treated & 125.78 & 136.49 & 323.25 & 403.30 & 134.23 & 224.49 \\
\hline Apparently healthy & 134.67 & 128.87 & 366.08 & 465.73 & 130.50 & 245.18 \\
\hline Apparently healthy-treated & 138.30 & 175.70 & 351.93 & 502.03 & 136.30 & 260.86 \\
\hline Cutting means & 125.45 & 123.03 & 300.74 & 417.00 & 121.29 & \\
\hline
\end{tabular}

1 The data are imperfect in that by Mar. 10, 1954, 59 apparently healthy plants were growing in the diseased plots, and there were a few diseased plants in the healthy plots: 4 in the diseased-treated; 4 in the apparently healthy-treated; and 11 in the apparently healthy.

2 Least significant difference between: 2 treatment means at 5 percent, 14.72 , at 1 percent, $19.49 ; 2$ cutting means at 5 percent, 16.47 , at 1 percent, $21.78 ; 2$ means of different treatments within same cutting at 5 percent, 32.89 , at 1 percent, 43.58 .

effort to compensate for its weakness and obtain approximately equal stands. A minimum of irrigation water was used, and a light application of nitrogenous fertilizer was added following the second harvest. The plots (fig. 1) were maintained weed-free. The grass was cut on five dates near the ground line, green weights were obtained, and analyses for nitrogen content made.

Germination was adequate in all plots. Differences in rate of grorrth were apparent from the first, but diseased plants became increasingly weaker with time. The production in the diseased plots was 65.3, 59.8, and 56.2 percent (table 2) of that in the apparently healthy-treated plots in five harvests obtained from the experiment. These observations indicate that Merker grass suffers more severely from this disease than the sugarcane grown commercially in Puerto Rico.

In dry weather, the plants are severely stunted, the leaves are dull-green, curled, and wilted, a purple color is often marked in the leaf sheaths, and some mortality occurs. Although the disease usually develops and spreads naturally in humid areas, severe losses also occur during dry weather or when diseased seed of Merker grass is planted in arid regions. When water is abundant the grass appears to be more tolerant to the disease.

The disease delayed flower emergence of $P$. purpureum (fig. 2), and the total nitrogen ${ }^{5}$ content of diseased plants exceeded that of healthy plants.

${ }^{5}$ Analyses made under the supervision of A. Riera, Agricultural Experiment Station, Río Piedras, P. R. 


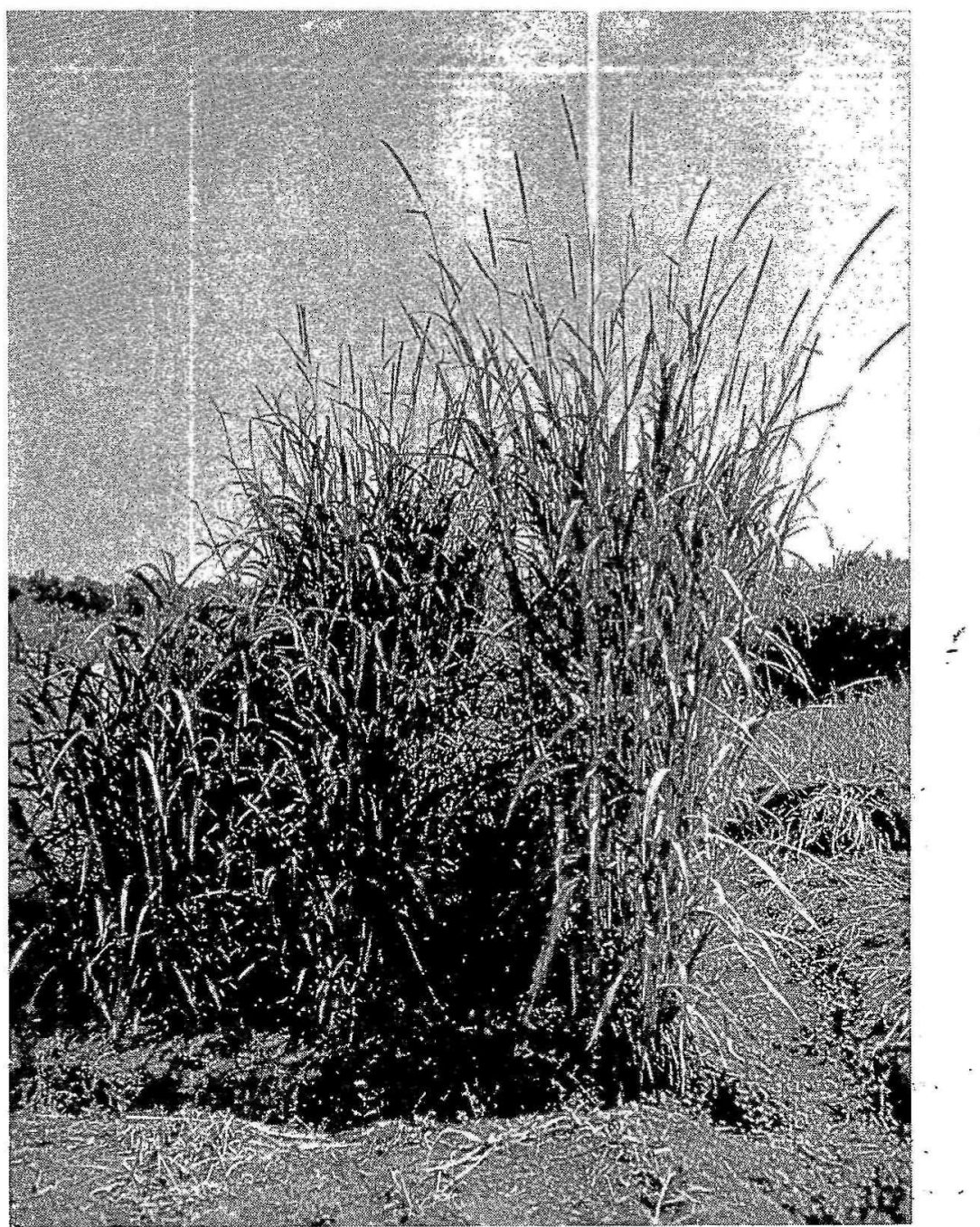

Fig. 2.--Flowering of Merker grass (Pennisetum purpureum) was delayed by chlorotic streak disease: Left-hand plant moderate to severely diseased, center plant lightly diseased, right-hand apparently healthy.

Delayed flowering and increased protein content (9.15 percent of protein in diseased, 7.76 percent of protein in healthy) both indicate an interference with normal maturation.

\section{DISCUSSION AND SUMMARY}

The chlorotic streak disease of Merker grass (Pennisetum purpureum Schumac.) has many features in common with the chlorotic streak disease 
of sugarcane. The leaf symptoms are similar. Both are carried in seed pieces, and seed of both is rendered disease-free by submerging in hot water $\left(52^{\circ} \mathrm{C}\right.$.) for 20 minutes. The diseased grass usually grew close to diseased sugarcane, or on a site adjacent to diseased cane. Infection in both cane $(1,6)$ and the grass results in heavy losses in tonnage. Some experiments with sugarcane $(1,6)$ report losses in sucrose as well as tonnage. In this work with Merker grass the chlorotic streak disease delayed maturity. Possibly, chlorotic streak disease of sugarcane upsets normal maturation under some conditions, and in this way lowers sugar yield. Until transmission studies have been made to determine the possible relationships between the chlorotic streak diseases of Merker grass and sugarcane, the observational evidence of their similarities 'seems strong enough to warrant proceeding on the assumption that they are caused by the same virus. Chlorotic streak-control programs in both hosts should advance together for the greatest safety.

\section{RESUMEN}

La eufermedad de la raya clorótica de la yerba ৯Ierker (Pennisetum purpureum Schumac) tiene muchos rasgos en común con la raya clorótica de la caña de azúcar. Los síntomas que presentan las hojas son similares. Ambas enfermedades pueden ir en la semilla y también ambas pueden evitarse si se sumerjen las semillas afectadas en agua caliente $\left(52^{\circ} \mathrm{C}\right.$.) por 20 minutos.

La yerba enferma con la raya clorótica se encontró, corrientemente, cerca de caña enferma con raya clorótica, o pudo localizarse el sitio de donde provenía la enfermedad que era también donde la caña estaba enferma. La infección en ambas cañas $(1,6)$ y en la yerba causó grandes pérdidas en el tonelaje. Algunos experimentos con caña de azúcar $(1,6)$ revelaron pérdidas en sacarosa y en tonelaje.

En este trabajo con yerba Merker se encontró que la enfermedad de la raya cloróticá retardó la madurez. Posiblemente, la enfermedad de la raya clorótica en la caña de azúcar trastorna su madurez normal bajo ciertas condiciones y de esta manera disminuye los rendimientos de azúcar.

No sería hasta que se hagan estudios de transmisión para determinar la posible relación entre las enfermedades de la raya clorótica que atacan la caña y la yerba Merker, que la evidencia de su semejanza podría garantizar firmemente el poder seguir suponiendo que ambas son causadas por el mismo virus.

El control de ambas enfermedades, tanto en la caña de azúcar como en la yerba Merker, deben propulsarse a la vez como medida de seguridad.

\section{LITERATURE CITED}

1. Abbott, E. V., Results of experiments with chlorotic streak in 1941, Sugar Bul. 20 $161-5,1942$. 